\title{
REVIEW ARICLE
}

\section{The Psychological Component of the Resource-Based Approach in Higher Pedagogical Education}

\author{
Authors' Contribution: \\ A - Study design; \\ B - Data collection; \\ C - Statistical analysis; \\ D - Data interpretation; \\ E - Manuscript preparation; \\ F - Literature search; \\ G - Funds collection
}

Background and Aim of Study:

Materials and Methods:

Results:

Conclusions:

Keywords:

Copyright:

DOI and UDC

Conflict of interests:

Peer review:

Source of support:

Information about the authors:
Mykytiuk S. O. ${ }^{1 \text { ABDEF, }}$ Mykytiuk S. S. ${ }^{\text {BEF }}$

${ }^{1}$ G. S. Skovoroda Kharkiv National Pedagogical University, Ukraine

${ }^{2}$ Yaroslav Mudryi National Law University, Ukraine

Received: 01.09.2019; Accepted: 23.09.2019; Published: 30.09.2019

\section{Abstract}

The integration of the resource-based approach into the management of the educational process in higher education institutions is essential since it allows to consider comprehensively the interaction of external and internal resources of the personality, which is important for the effective planning of educational activities aimed at high academic achievements, comprehensive personal development and successful professional formation.

The aim of the study: to determine the essence and significance of the psychological component, which is a part of the internal resource of the individual, in the structure of the resource-based approach and its role in the management of the educational process.

In the study, the following general scientific methods were used: analysis, comparison, generalization, literature systematization and interpretation of results.

The research reveals the constituent parts of the psychological resource that is considered as one of the key elements in most models of the personality structure or models of learning, determines their impact on the productivity of the educational process and personal and professional development of students.

Consideration of the psychological substructure (the level of development of cognitive processes, mental properties of the personality, specific features of the emotional and volitional sphere, prevailing motives for behaviour, etc.) in the management of the educational process facilitates the activation of the resources of personality, which, in turn, increases the motivation for cognitive activity, improves academic achievement, affects personal and professional formation, and allows creating conditions for personality self-development.

resource-based approach, external and internal resources, psychological resource, attention, thinking, memory, motive, personality self- development.

(C) 2019 Mykytiuk S. O., Mykytiuk S. S. Published by Archives of International Journal of Education and Science

DOI 10.26697/ijes.2019.3.1; UDC 378.147:37.025

The authors declare that there is no conflict of interests

Double-blind review

Departmental sources

Mykytiuk Serhii Oleksandrovych (Corresponding author) - https://orcid.org/00000003-0926-2237; sm220572@gmail.com; Doctor of Pedagogical Sciences, Professor, Professor of the Department of Philosophical and Psychological Anthropology; G. S. Skovoroda Kharkiv National Pedagogical University; Kharkiv, Ukraine.

Mykytiuk Svitlana Stepanivna - https://orcid.org/0000-0002-7264-0264; Doctor of Philosophy in Philology, Associate Professor of the Department of Foreign Languages No. 1; Yaroslav Mudryi National Law University; Kharkiv, Ukraine. 


\section{Introduction}

Transformations in Ukraine that occur under the influence of global cultural processes require the formulation of new conceptual and methodological provisions for the development of higher education institutions. An important direction of these changes is the further democratization of the management and the reform of the content structure of the educational process. This is a positive development but it requires strengthening of responsibility of educational process participants and a well-defined resource provision in the educational process: it is not possible to improve the level of education only by changing national or regional programs. An important condition is to reveal and develop the individual's potential abilities that are the basis for the development of the individual and the effectiveness of their activities.

The development of special organizational mechanisms with the detailed procedures enshrined in regulatory enactments as a mandatory principle can introduce the resource provision of the pedagogical process into the regime of effective organizational activities of institutions of higher professional education.

The aim of the study. To determine the essence and significance of the psychological component, which is a part of the internal resource of the individual, in the structure of the resource-based approach and its role in the management of the educational process.

\section{Materials and Methods}

In the study, the following general scientific methods were used: collection of information, analysis, synthesis, comparison, and generalization.

\section{Results}

Pointing to the dominant role of the resource in all spheres of human activity, scholars have been forming a system of views on its essence and place in society for centuries. The methodological principles of the resource-based approach were first formulated in classical works on the economic theory of profit and competition by Penrose (1959), Porter (1980), and Schumpeter (1934).

In the 1990s the resource-based approach was formed as a new scientific direction of the theory of strategic management and received theoretical substantiation in the fundamental works by Teece, Pisano, and Shuen (1997), Wernerfelt (1995) and others. Griffin (1997), Onah (2012) and others have studied human resource management issues not only in the enterprise but also in education.

The resource-based approach in political and sociological research has been developed in the works by Ledyayev (2001), Tretiak (2014), Zaslavskaya (2005) and other scholars who have revealed the essence of the key concepts of "resources" and "abilities".

The research on the resource-based approach has been conducted in the following areas:

- theoretical issues on the nature of the individual's development resources and their types (Akbasheva,
1999; Kondakov, 2005; Shamova \& Davidenko, 2001 and others);

- the connection between the development of potential abilities and self-development of the individual (Abulkhanova-Slavskaya, 1980; Derkach, 2004; Ignatyuk, 2009; Sitnikova, 2007 and others);

- the formation of the spiritual and creative potential of the individual (Chaplygin, 1999; Sohan, 2003 and others), mental potential of the individual (Melnyk \& Stadnik, 2018 and others), innovative potential of the individual (Melnyk \& Pypenko, 2017 and others);

- the development of professional competences based on the resource approach (Ibrahim, 2010; Romanovskyi, Mykhailychenko, \& Hren, 2011 and others);

- individualization in teacher training (Beh, 1991; Rohova, 2006 and others).

The authors state that the resource approach studies the individual's abilities, considers a person as the individual who has certain potential abilities that can be realized under certain conditions and sees a person in the future in terms of prospects for the implementation of potential abilities with the goal of new positive qualitative changes.

Consideration of various types of resources in the training of specialists facilitates the activation of reserve abilities that a person can use for optimal selfrealization.

Analysing the development of the personality, scholars distinguish external and internal resources. The study of the scientific works by Allayarov (2002), Gershunskiy (2003), Ibrahim (2010) and others allows us to define the following resources as external ones: material and technical resources (objects of the outside world, which to some extent affect the activity of the individual); information resources (generalized experience of humanity in oral and written form, virtual information: computer technologies, the access to them); stimulating resources (moral and material encouragement, punishment, formation of positive motivation, external evaluation of activities, selfappraisal, etc.); communicative and psychological resources (specific features of the conditions of communication and organization of interpersonal interaction, the emotional and psychological climate in the team, team cohesion, the main communication style, etc.); organizational and managerial resources (the system of management of the educational process, the consistency of requirements of teachers to students, the quality of the compiled schedule, etc.). It is illustrated in Figure 1.

Unlike external resources, internal ones determine the uniqueness of the individual, they are the source of their development and personalization. In the system of internal (individual) personal abilities, scholars distinguish the following subsystems: the biogenetic subsystem, related to heredity; the physiological subsystem (the state of health, structural features of the body, physical endurance, age, gender, etc.); the individual-psychological subsystem (level of intellectual development, especially emotionalvolitional sphere, etc.). It is illustrated in Figure 2. 
It is indisputable that in the process of becoming a professional a special "professional" type of personality is formed in the individual, which is different from the personality of the individual who is not a professional in this type of activity. Klimov (2003) argues that it is necessary to consider professionalism not only as a high level of knowledge, skills and results in a definite field of human activity but also as a certain systemic organization of the psyche, that is, professionalism is a certain systemic trait of the individual (a system of appropriately organized components).

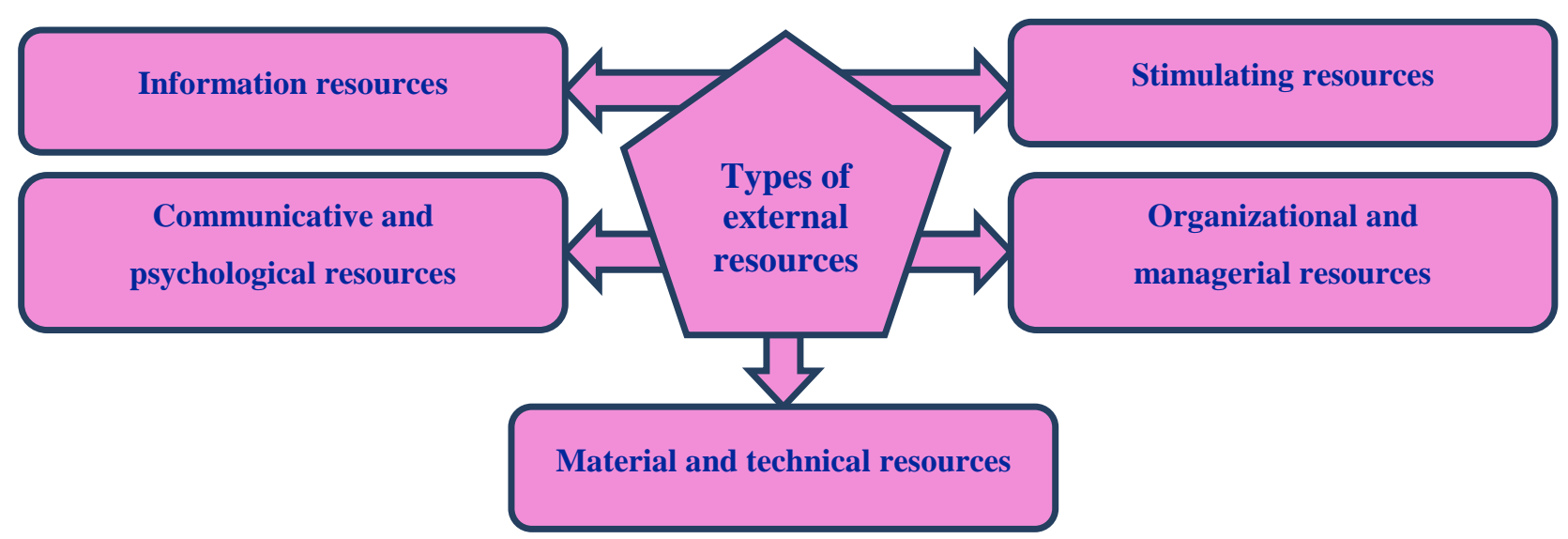

Figure 1. Types of external resources of the personality.

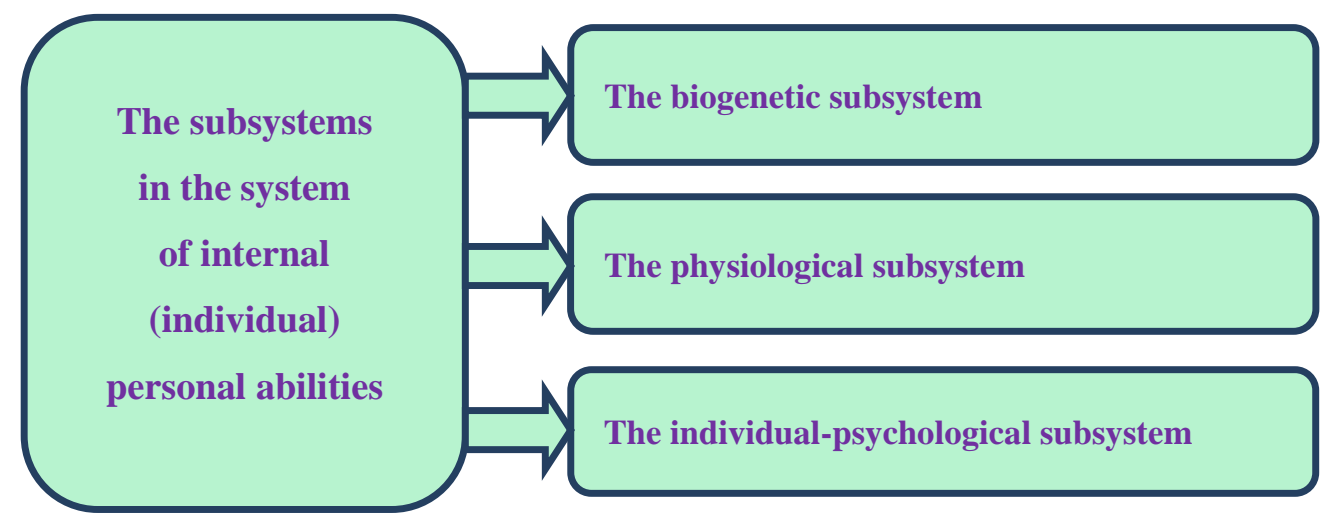

Figure 2. The system of internal (individual) personal abilities.

According to Druzhilov (2003), the concept "professionalism" reflects that level of mastering the psychological structure of professional activity which meets the existing standards in society and objective requirements. The notion "professionalism" is not limited to the characteristics of highly skilled labour; it is also a special outlook of a person.

The personality of a professional who has passed a sufficiently long period of theoretical training and subsequent adaptation to practical activity and has acquired the necessary professional experience should be considered as professionally conditioned. In the psychological literature, there are different views on the personality traits of a professional.

For example, Zeer (2005) identifies four sub-structures in the structure of a professional's personality: 1) the substructure of professionally significant psychophysiological characteristics (neuroticism, extraversion, reactivity, etc.); 2) the substructure of professionally important qualities; 3) the substructure of professional competence; 4) the substructure of professional orientation.

Markova (1996) defines the ability to acquire independently new knowledge and skills as well as to use them in practice independently as one of the most important components of professional competence. The authors who deal with the issue of professional competence single out psychological characteristics of the personality of the professional as one of the components in its structure, the consideration and development of which are a condition for effective professional development.

The structure of the psychological resource includes motives of activity, cognitive processes (attention, feeling, perception, memory, thinking, imagination); volitional processes (persistence, commitment, discipline) and emotional processes (feelings, emotional state).

The success or effectiveness a person's particular activity depends not only on their abilities but also, to a great extent, on the development of a certain level of motivation for it. There is a complex system of interconnections between these two factors. Under certain conditions, if a person has reached a high level in a particular activity, the so-called compensatory mechanism may be activated. In these circumstances, the lack of ability is compensated by the development of the person's motivational sphere (the interest in the 
subject, awareness of the choice of profession, desire to identify or improve their potential, etc.), and the subject of training becomes capable of achieving considerable success.

This opinion is supported by the research results of Yakunin and Platonova (1993), Nesterova (2012) who prove that the formation of a future highly qualified specialist is possible only if motivation and values concerning the profession are formed and the success of training and self-realization of students in professional activity are determined by the strength and stability of motives, their plurality, structure and hierarchy.

That is, a motive is an integral way of organizing human activity, an incentive, the determinants of which are both internal and external causes. It performs selective, cognitive, demanding, stimulating, and content-regulatory-executive and formative functions.

The success of learning activities depends largely on the level of development of attention. It is a dynamic process and can vary depending on many factors. Attention can change its intensity throughout the day (Peter, Ellers, Hanecke, \& Nachreiner, 1987).

Each person has individual characteristics of the manifestation of attention, which are determined by the influence on the person of both social and biological factors, one of which is the individual typological features of higher nervous activity. Studying the relationship between the strength of nervous processes and concentration of attention, a number of authors have come to the conclusion that people with strong characteristics of this property concentrate attention better. Functional mobility and lability of nervous processes create physiological conditions for the realization of a greater scope of attention while with less mobility, the weak and inert nervous system the scope of attention decreases. Thus, the leading role in the realization of the scope of attention is played by the functional mobility of the nervous processes (Chaichenko, H., Tomilina, Postova, \& Chaichenko, Zh., 1994).

As we know, the link between the past, present and future in the life and activities of a person is in their memory. Different types of memory (imaginative, verbal-logical, motor, emotional, involuntary and arbitrary, short-term, long-term, operative) are manifested differently by subjects in speed, accuracy, memory strength and readiness for reproduction.

Students of pedagogical institutions develop memory for people, they better remember the manifestations of their feelings, peculiarities of behaviour, biographical data. However, this memory does not appear suddenly. It must be purposefully developed and improved in accordance with the requirements of the future profession.

Therefore, the psychophysiological properties of students' memory should be considered as one of the main factors of psychophysiological readiness for professional (in particular, pedagogical) activity in the complex and long process of vocational training. It is important to take into account individual memory differences in educational work in order to maximize the potential use of each student's abilities and to develop them fully.

It should be noted that the work of the teacher is characterized by considerable strain of mental activity. This is due, firstly, to the specificity of the profession, the main task of which is to organize the process of mastering knowledge by students, and secondly, to the considerable workload that requires the teacher to spend daily both mental and physical potential. In the professional activity of the teacher, two types of thinking are organically and inseparably combined: theoretical and practical.

The profession of the teacher requires constant expansion of knowledge about the development of various spheres of social life, science, technology, and culture. This is explained not only by ordinary cognitive interest, but also by an attempt to deeply comprehend life's phenomena and events. The development of a worldview, general culture, and a wide range of interests is an important indicator of the teacher's development as a personality, which is crucial for characterizing their activities as a professional teacher. Only in the context of knowledge of the methodological problems of scientific thought, social and cultural life of society a teacher can productively, at a high level of competence, solve such fundamentally important tasks as selecting the content of training sessions, choosing the most effective methods for teaching, diagnostics and prediction of the student's personality.

According to Slastenin (1976), the teacher's ability to think independently and creatively is the highest level of pedagogical skill. Using the already known pedagogical techniques, the teacher should be able to enrich them with their thought, their vision of the problem. The creative thinking of the teacher is directly involved in their activity and aimed at solving various pedagogical problems. The main purpose of these tasks is to develop the personality of the student in the process of education, and the condition for achieving this goal is the organization of the students' intense work. We believe that the educational process at a higher education institution should be aimed at equipping the student with knowledge not only in the basics of science, but also in ways of acquiring this knowledge in a more rational way, in the shortest possible time and without sacrificing one's own health and well-being.

So, arming students of higher pedagogical educational institutions with knowledge about the culture of mental work is one of the main tasks, since only having their own experience, they can learn effectively, become qualified specialists, and therefore can transfer this experience to others, that is, future pupils.

In addition to the cognitive qualities of the personality, it is necessary to take into account and develop, as noted by Markova (1996), psychosocial qualities, which include emotional qualities: curiosity, management of negative emotions; volitional qualities; communicative qualities: tolerance, the ability to listen and hear, ability to take into account the specific features of the interlocutor, and openness. 
Emotions are the "internal regulator" of activities, they serve as the organizing and motivating factor of human behaviour. According to Rubinstein (Kulikov, 2009) subjective experiences not only accompany but also actively participate in the regulation of activities and reflect the desired states of the subject. Emotions as human experiences of different needs act as the genetic source of the expansion of activities.

In Gonobolin's work (1965) the approach to the study of the individually stable properties of the teacher as an external resource, which facilitate successful pedagogical activity, is considered. The author refers to the known facts which prove that the indifference, lack of emotionality of the teacher impedes the successful work of the teacher. One of the important qualities of the teacher is the ability to manage their emotions. Success in pedagogical work is determined not only by the strength and speed of the feelings, but also by the extent of their external manifestation (facial expressions, gestures of emotional language, etc.). The importance of bilateral orientation of emotional processes in educational purposes is emphasized. It is noted that emotionality and love for their profession is one of the main conditions that provide psychological opportunity for creative work of the teacher. The emphasis is placed on the structure of relationships in the team, pedagogical creativity, and pedagogical tact and special attention is paid to the emotional component.

One of the educational tasks according to the author is to develop and to strengthen in the child optimistic confidence in the possibility of overcoming difficulties, especially intellectual difficulties, related to learning. The condition for the implementation of this task is the creation of an atmosphere of creative competition of thought in the team.

The role of the resource approach in the psychological support of the educational process at the higher pedagogical institution is to establish the relationship of self-realization of the individual with their potential abilities of the psyche, to create conditions for the development of the essential forces of the personality, the possibility of realizing their efforts on the way to positive results.

The perspective direction of the problem development is the analysis of the conditions of the use of different groups of resources to form a positive emotional background of the pedagogical process.

\section{Discussion}

The analysis of the scientific works based on the theoretical and methodological foundations of the resource-based approach showed the directions of researches: the conditions of social and pedagogical activity for the sustainable development of social groups (Kabus, 2015); managing human resources in teacher training (Rafiei \& Davari, 2015); strategic management of the activity of a comprehensive educational institution (Udovichenko \& Tymchenko, 2019); preparing future physics teachers for innovative activity (Sukhovirskaya, 2017); formation of individual style of professional activity of a future nursery teacher (Kolosova, 2017); "resource" approach to mathematics education (Trouche, Gueudet, \& Pepin, 2019). These studies confirm the importance and need for further development of methodological recommendations for improving the productivity of the educational process at higher education institutions on the basis of the resource-based approach.

\section{Conclusions}

To summarize all of the above, we can conclude that nowadays the resource-based approach is becoming increasingly popular with researchers working in various fields of the humanities, technical and natural sciences. It can be explained by the fact that it provides an opportunity to consider comprehensively the interaction of resources that are caused by external factors and the internal abilities of a subject of activity. The system of internal resources of the personality consists of various substructures, one of which is a psychological one (the level of development of cognitive processes, mental properties of the personality, specific features of the emotional and volitional sphere, prevailing motives for behaviour, etc.). Consideration of this substructure in the educational process will not only increase the motivation for cognitive activity but also will create the conditions for students' self-development.

\section{References}

Abulhanova-Slavskaya, K. A. (1980). Deyatelnost $i$ psihologiya lichnosti [Activity and personality psychology]. Moscow: Nauka. [in Russian]

Akbasheva, R. Sh. (1999). Proektniy podhod $k$ lichnostnoти obrazovaniyu [Project approach to personal education]. Ufa: BGPI. [in Russian]

Allayarov, Z. A. (2002). Pedagogicheskie usloviya lichnostno-professionalnogo razvitiya uchitelya $v$ munitsipalnoy sisteme obrazovaniya [Pedagogical conditions of personal and professional development of a teacher in the municipal education system] (Doctoral thesis, Bashkir State Pedagogical University, Ufa, Russia). Retrieved from http://www.dslib.net/ [in Russian]

Ananev, B. G. (2002). Chelovek kak predmet poznaniya [Man as a subject of knowledge]. St. Petersburg: Piter. [in Russian]

Beh, I. D. (1991). Nravstvennost lichnosti: strategiya stanovlennya [Personality morality: The formation strategy]. Rovno. [in Russian]

Bloom, B. S. (1984). Taxonomy of educational objectives: The classification of educational goals. New York: Longman.

Chaichenko, H. M., Tomilina, L. H., Postova, O. V., \& Chaichenko, Zh. H. (1994). Kompleksnyi pidkhid do otsinky psykhofiziolohichnoho stanu liudyny [A comprehensive approach to the assessment of human psychophysiological status]. Fiziolohichnyi zhurnal - Physiological Journal, 1, 22-27. [in Ukrainian]

Chaplygin, O. K. (1999). Tvorchiy potentsIal lyudini: vid stanovlennya do realizatsiyi (sotsialnofilosofskiy analiz) [Human creativity: from origin to realization (socio-philosophical analysis)]. Kharkiv: Osnova. [in Ukrainian] 
Derkach, A. A. (2004). Akmeologicheskie osnovyi razvitiya professionala [Acmeological basis for professional development]. Moscow: Izd-vo Mosk. psihol.-sociol. in-ta; Voronezh: NPO "MODJeK". [in Russian]

Druzhilov, S. A. (2003). Professionalizm cheloveka kak obekt psihologicheskogo izucheniya: sistemnyiy podhod [Human professionalism as an object of psychological study: A systematic approach]. Vestnik Baltiyskoy pedagogicheskoy akademii - Bulletin of the Baltic Pedagogical Academy, 52, 40-46. [in Russian]

Dugguh, S. I. (2007). Human resource management. Nigeria: Oracle Ltd.

Gershunskiy, B. S. (2003). Kontseptsiya samorealizatsii lichnosti v sisteme obosnovaniya tsennostey i tseley obrazovaniya [The concept of personal self-realization in the system of justification of values and educational goals]. Pedagogika - Pedagogics, 10, 3-7. [in Russian]

Gonobolin, F. N. (1965). Kniga ob uchitele [The book about the teacher]. Moscow: Prosveshenie. [in Russian]

Griffin, R. W. (1997). Management. Delhi: A. I. T. B. S Publishers.

Ibrahim, Yu. S. (2010). Formuvannia kultury rozumovoi pratsi studentiv vyshchykh pedahohichnykh navchalnykh zakladiv $u$ protsesi navchannia [Formation of culture of mental work of students of higher pedagogical institutions in the process of learning] (Doctoral thesis, H. S. Skovoroda Kharkiv National Pedagogical University, Kharkiv, Ukraine). Retrieved from http://www.irbis-nbuv.gov.ua [in Ukrainian]

Ignatyuk, O. A. (2009). Formuvannya maybutnogo inzhenera do profesiynogo samovdoskonalennya: teoriya $i$ praktika [Forming the Future Engineer for Professional Self-Improvement: Theory and Practice]. Kharkiv: NTU "KhPI". [in Ukrainian]

Klimenko, N. O. (2005). Formuvannya motiviv navchalno-piznavalnoyi diyalnosti studentiv vishih navchalnih zakladiv gumanitarnogo profilyu [Formation of motives of educational and cognitive activity of students of higher educational institutions of the humanitarian profile] (Doctoral abstract, Taras Shevchenko Lugansk National Pedagogical University, Lugansk, Ukraine). Retrieved from http://www.irbis-nbuv.gov.ua [in Ukrainian]

Klimov, E. A. (2003). Puti v professionalizm (Psihologicheskiy analiz) [Ways to Professionalism (Psychological Analysis)]. Moscow: Mosk. psihol.-sots. in-t; Flinta. [in Russian]

Kondakov, A. M. (2005). Obrazovanie kak resurs razvitiya lichnosti, obschestva $i$ gosudarstva [Education as a resource for the development of the individual, society and the state] (Doctoral thesis, Institute for Content and Teaching
Methods of the Russian Academy of Education, Moscow, Russia). Retrieved from http://naukapedagogika.com [in Russian]

Kulikov, L. V. (2009). Psihologiya lichnosti v trudah otechestvennyih psihologov [Psychology of personality in the works of domestic psychologists]. Saint Petersburg. [in Russian]

Ledyaev, V. G. (2001). Vlast: kontseptualnyiy analiz [Power: conceptual analysis]. Moscow: ROSSPEN. [in Russian]

Markova, A. K. (1996). Psihologiya professionalizma [Psychology of professionalism]. Moscow: International Humanitarian Fund "Knowledge". [in Russian]

Melnyk, Y., \& Pypenko, I. (2017). Innovative potential of modern specialist: The essence and content. In Yu. B. Melnyk (Ed.), Psychological and pedagogical problems of modern specialist formation (pp. 9-16). Warsaw: ANAGRAM; KRPOCH.doi:10.26697/9789669726094.2017.9

Melnyk, Yu., \& Stadnik, A. (2018). Mental health of a personality: Diagnostics and prevention of mental disorders. International Journal of Education and Science, 1(3-4), 50. doi:10.26697/ijes.2018.3-4.37

Mykytiuk, S. O. (2012). Osobystisnyi resurs uchytelia u strukturi pedahohichnoi maisternosti [Personal resource of the teacher in the structure of pedagogical mastery]. Zasoby navchalnoi ta naukovo-doslidnoi roboty - Means of Educational and Research Work, 37, 72-80. [in Ukrainian]

Mykytiuk, S. O. (2012). Osvitnie seredovyshche yak resurs yakosti pidhotovky pedahohiv u VNZ [Educational environment as a resource for the quality of teacher training at higher educational institutions]. Pedahohichni nauky teoriia, istoriia, innovatsiini tekhnolohii - Pedagogical sciences: theory, history, innovative technologies, 6, 231-241. [in Ukrainian]

Nesterova, N. B. (2012). Ierarhicheskaya struktura motivatsionno-tselevoy osnovyi ucheniya studentov [The hierarchical structure of the motivational and purpose oriented basis for student training]. Nauchnyiy zhurnal NIU ITMO. Seriya "Ekonomika $i$ ekologicheskiy menedzhment” - Scientific Journal of NRU ITMO. Series "Economics and Environmental Management", 2(11), 350-354. [in Russian]

Onah, F. O. (2012). Engaging the challenges of human resources management in public organizations in Nigeria. Nsukka, Nigeria.

Penrose, E. T. (1959). The theory of the growth of the firm. Oxford: Basil Blackwell.

Peter, J., Ellers, K., Hanecke, K., \& Nachreiner, F. (1987). Time of day effects in vigilance performance and its predictability. Contemporary Advanced Shift - work Results: Theory and Practical Aspects Late Eighties. Krakow, Poland.

Porter, M. E. (1980). Competitive strategy: Techniques for analyzing industries and competitors. New 
York.

Rafiei, N., \& Davari, F. (2015). The role of human resources management on enhancing the teaching skills of faculty members. Materia Socio-Medica, 27(1), 35-38. doi:10.5455/msm.2014.27.35-38

Rohova, T. V. (2006). Personalizovanyi pidkhid $v$ upravlinni pedahohichnym kolektyvom shkoly [A personalized approach to managing the school's teaching staff]. Kharkiv: PPV Nove slovo. [in Ukrainian]

Romanovskyi, O. H., Mykhailychenko, V. Ye., \& Hren, L. M. (2011). Pedahohika uspikhu [Pedagogy of success]. Kharkiv: NTU "KhPI". [in Ukrainian]

Sallis, E. (2014). Total quality management in education (3rd ed.). London: Taylor \& Francis.

Schumpeter, J. A. (1934). The theory of economic development. Cambridge, Mass: Harvard University Press.

Shamova, T. I., \& Davidenko, T. M. (2001). Upravlenie obrazovatelnyim protsessom $v$ adaptivnoy shkole [Educational process management in an adaptive school]. Moscow: Tsentr "Ped. poisk". [in Russian]

Sitnikova, M. I. (2007). Kultura samorealizatsii prepodavatelya vuza $v$ pedagogicheskoy deyatelnosti [The culture of self-realization of a university teacher in pedagogical activity]. Moscow-Belgorod: BelGU. [in Russian]

Slastenin, V. A. (1976). Formirovanie lichnosti uchitelya sovetskoj shkoly $v$ processe professionalnoj podgotovki [The formation of the personality of the teacher of the Soviet school in the process of training]. Moscow: Prosveshhenie. [in Russian]

Sohan, L. V. (2003). Zhitteva kompetentnist osobistosti [The vital competence of the individual]. Kyiv: Bogdana. [in Ukrainian]

Teece, D., Pisano, G., \& Shuen, A. (1997). Dynamic capabilities and strategic management. Strategic Management Journal, 18(7), 509-533.

Tretiak, O. P. (2014). Suchasni personal-tekhnolohii u systemi upravlinnia personalom na pidpryiemstvi [Modern staff technologies in the personnel management system at the enterprise]. Naukovyi visnyk NLTU - Scientific Bulletin of NLTU of Ukraine, 24(4), 389-397.

Trouche, L., Gueudet, G., \& Pepin, B. (Eds.). (2018). The "Resource" Approach to Mathematics Education. Springer International Publishing. doi:10.1007/978-3-030-20393-1

VanGundy, A. (2005). 101 Activities for teaching creativity and problem solving. San Francisco: Pfeiffer.

Wagenaar, R. (2014). Competences and learning outcomes: A panacea for understanding the (new) role of Higher Education? Tuning Journal for Higher Education: Competence-based learning: a global perspective, 1(2), 279-302.

Wernerfelt, B. (1995). The resource-based view of the firm: Ten years after. Strategic Management Journal, 16(3), 171-174.
Yakunin, V. A., \& Platonova, I. M. (1993). Teoriya obucheniya [The theory of education]. Saint Petersburg: Izd-vo SPbGU. [in Russian]

Zaslavskaya, T. I. (2005). Chelovecheskiy potentsial v sovremennom transformatsionnom protsesse [Human potential in the modern transformational process]. Obschestvennyie nauki i sovremennost - Social Sciences and Modernity, 3, 5-16. [in Russian]

Zeer, E. (2005). Modernizatsiya professionalnogo obrazovaniya: kompetentnostnyiy podhod [Modernization of vocational education: competency-based approach]. Moscow: MSPI. [in Russian]

\section{Література}

Абульханова-Славская К. А. Деятельность и психология личности. Москва: Наука, 1980. $287 \mathrm{c}$.

Акбашева Р. Ш. Проектний подход к личностному образованию. Уфа: БГПИ, 1999. 132 с.

Аллаяров 3. А. Педагогические условия личностнопрофессионального развития учителя в муниципальной системе образования: дис. ... канд. пед. наук: 13.00.01/Башкир. гос. педаг. ун-т Уфа, 2002. $172 \mathrm{c}$

Ананьев Б. Г. Человек как предмет познания. Санкт-Петербург: Питер, 2002. 288 с.

Бех И. Д. Нравственность личности: стратегия становлення. Ровно, 1991. 146 с.

Bloom B. S. Taxonomy of educational objectives: The classification of educational goals. New York: Longman, 1984.

Комплексний підхід до оцінки психофізіологічного стану людини/Чайченко Г. М. та ін. Фізіологічний журнал. 1994. № 1. С. 22-27.

Чаплигін О. К. Творчий потенціал людини: від становлення до реалізації (соціальнофілософський аналіз). Харків: Основа, 1999. $277 \mathrm{c}$.

Деркач А. А. Акмеологические основы развития профессионала. Москва: Изд-во Моск. психол.-социол. ин-та; Воронеж: НПО "МОДЭК”, 2004. 752 с.

Дружилов С. А. Профессионализм человека как объект психологического изучения: системный подход. Вестник Балтийской педагогической академии. 2003. Вып. 52. C. $40-46$.

Dugguh S. I. Human Resource Management. Nigeria: Oracle Ltd, 2007.

Гершунский Б. С. Концепция самореализации личности в системе обоснования ценностей и целей образования. Педагогика. 2003. № 10. C. 3-7.

Гоноболин Ф.Н. Книга об учителе. Москва: Просвещение, 1965. 260 с.

Griffin R. W. Management. Delhi: A. I. T. B. S Publishers, 1997.

Ібрагім Ю. С. Формування культури розумової праці студентів вищих педагогічних навчальних закладів у процесі навчання: дис. ... канд. пед. наук: 13.00.09/Харк. нац. педаг. 
ун-т ім. Г. С. Сковороди Харків, 2010. 235 с.

Ігнатюк О. А. Формування майбутнього інженера до професійного самовдосконалення: теорія і практика. Харків: НТУ “ХПІ”, 2009. 432 с.

Клименко Н. О. Формування мотивів навчальнопізнавальної діяльності студентів вищих навчальних закладів гуманітарного профілю: автореф. дис. на здобуття наук. ступеня канд. пед. наук: 13.00.04 Луганськ, 2005. 22 с.

Климов Е.А. Пути в профессионализм (Психологический анализ). Москва: Моск. психол.-соц. ин-т; Флинта, 2003. 320 с.

Кондаков А. М. Образование как ресурс развития личности, общества и государства: дис. ... дра пед. наук: 13.00.01/Институт содержания и методов обучения Российской академии образования Москва, 2005. 322 с.

Куликов Л. В. Психология личности в трудах отечественных психологов. СанктПетербург: Питер, 2009. 227 с.

Ледяев В. Г. Власть: концептуальный анализ. Москва: РОССПЭН, 2001. 384 с.

Маркова А. К. Психология профессионализма. Москва: Международный гуманитарный фонд “Знание”, 1996. 312 с.

Melnyk Y., Pypenko I. Innovative potential of modern specialist: The essence and content. Psychological and pedagogical problems of modern specialist formation/in Yu. B. Melnyk (Ed.). Warsaw: ANAGRAM; KRPOCH, 2017. P. 9-16. doi:10.26697/9789669726094.2017.9

Melnyk Yu., Stadnik A. (2018). Mental health of a personality: diagnostics and prevention of mental disorders. International Journal of Education and Science. Vol. 1. № 3-4. P. 50. doi:10.26697/ijes.2018.3-4.37

Микитюк С. О. Особистісний ресурс учителя у структурі педагогічної майстерності. Засоби навчальної та науково-дослідної роботи. 2012. Вип. 37. С. 72-80.

Микитюк С. О. Освітнє середовище як ресурс якості підготовки педагогів у ВНЗ. Педагогічні науки: теорія, історія, інновачійні технології. 2012. № 6. С.231-241.

Нестерова Н. Б. Иерархическая структура мотивационно-целевой основы учения студентов. Научный журнал НИУ ИТМО. Сер. «Экономика и экологический менеджмент. 2012. № 2(11). Р. 350-354.

Onah F. O. Engaging the challenges of human resources management in public organizations in Nigeria. Nsukka, Nigeria, 2012.

Penrose E. T. The Theory of the Growth of the Firm. Oxford: Basil Blackwell, 1959.

Time of day effects in vigilance performance and its predictability/Peter J. and others. Contemporary Advanced Shift - work Results: Theory and Practical Aspects Late Eighties. Krakow, Poland, 1987.

Porter M. E. Competitive Strategy: Techniques for Analyzing Industries and Competitors. New York, 1980.
Rafiei N., Davari F. The Role of Human Resources Management on enhancing the teaching skills of faculty members. Materia Socio-Medica. 2015. $\begin{array}{lll}\text { Vol. } 27 . & \text { Iss. 1. } & \text { P. 35-38. }\end{array}$ doi: $10.5455 / \mathrm{msm} .2014 .27 .35-38$

Рогова Т. В. Персоналізований підхід в управлінні педагогічним колективом школи. Харків: ППВ Нове слово, 2006. 299 с.

Романовський О.Г., Михайличенко В. Є., Грень Л. М. Педагогіка успіху. Харків: НТУ “ХПІ”, $2011.368 \mathrm{c}$.

Sallis E. Total quality management in education. 3rd ed. London: Taylor and Francis, 2014.

Schumpeter J. A. The Theory of Economic Development. Cambridge, Mass: Harvard University Press, 1934.

Шамова Т. И., Давиденко Т. М. Управление образовательным процессом в адаптивной школе. Москва: Центр “Пед. поиск”, 2001. $384 \mathrm{c}$.

Ситникова М. И. Культура самореализации преподавателя вуза в педагогической деятельности. Москва-Белгорорд: Изд-во БелГУ, 2007. 280 с.

Сластенин В. А. Формирование личности учителя советской школы в процессе профессиональной подготовки. Москва: Просвещение, 1976. 160 с.

Сохань Л. В. Життєва компетентність особистості. Київ: Богдана, 2003. 520 с.

Teece D., Pisano G., Shuen A. Dynamic Capabilities and Strategic Management. Strategic Management Journal. 1997. Vol. 18. No. 7. P. 509-533.

Третьяк О. П. Сучасні персонал-технології у системі управління персоналом на підприємстві. Науковий вісник НЛТУ України. 2014. Вип. 24.4. С. 389-397.

The "Resource" Approach to Mathematics Education/in L. Trouche (Ed.). Springer International Publishing, 2018. doi:10.1007/978-3-030-20393-1

VanGundy A. 101 Activities for teaching creativity and problem solving. San Francisco: Pfeiffer, 2005.

Wagenaar R. Competences and learning outcomes: a panacea for understanding the (new) role of Higher Education? Tuning Journal for Higher Education: Competence-based learning: a global perspective. 2014. Vol. 1. Iss. 2. P. 279-302.

Wernerfelt B. The Resource-Based View of the Firm: Ten Years After. Strategic Management Journal. 1995. Vol. 16. № 3. P. 171-174.

Якунин В. А., Платонова И. М. Теория обучения. Санкт-Петербург: Изд-во СПбГУ, 1993. 96 с.

Заславская Т.И. Человеческий потенциал в современном трансформационном процессе. Общественные науки и современность. 2005. № 3. C. 5-16.

Зеep Э.Ф. Модернизация профессионального образования: компетентностный подход. Москва: МСПИ, 2005. 354 с. 
Психологічний компонент ресурсного підходу у вищий педагогічній освіті

Микитюк С. O. ${ }^{1}$, Микитюк С. C. ${ }^{2}$

${ }^{1}$ Харківський національний педагогічний університет імені Г. С. Сковороди, Україна

${ }^{2}$ Національний юридичний університет імені Ярослава Мудрого, Україна

\begin{abstract}
Анотація
Bступ: Інтегрування ресурсного підходу в управлінні навчальним процесом у закладах вищої освіти має суттєве значення, оскільки він дає можливість всебічно урахувати взаємодію зовнішніх та внутрішніх ресурсів особистості, щзо $\epsilon$ важливим для ефективного планування навчальної діяльності, метою якої $\epsilon$ високі академічні досягнення, всебічний розвиток особистості та успішне професійне становлення.

Мета дослідження: Визначити сутність та значення психологічного компоненту, щз $\epsilon$ складовою внутрішнього ресурсу особистості, в структурі ресурсного підходу та його роль в управлінні навчальним прочесом.
\end{abstract}

матеріали $\boldsymbol{i}$ Методи: У використовувались такі загальнонаукові методи: аналіз, синтез, порівняння, узагальнення, систематизація літератури та інтерпретація результатів.

Результати: У дослідженні виявлено складові частини психологічного ресурсу, щцо розглядається як один із ключових елементів більшості моделей структури особистості та навчання, визначено їх вплив на продуктивність навчального процесу, особистий та професійний розвиток студентів.

Висновки: Урахування психологічної підструктури (рівень розвитку пізнавальних процесів, психічні властивості особистості, особливості емоиійновольової сфери, переважаючи мотиви поведінки $i$ m. n.) y ходi управління навчальним процесом сприяє активізаиії ресурсів особистості, щзо, у свою чергу, підвищуе мотивацію до пізнавальної діяльності, покращує навчальні досягнення, впливає на особисте та професійне становлення та дозволяе створити умови для саморозвитку особистості.

Ключові слова: ресурсний підхід, зовнішні та внутрішні ресурси, психологічний ресурс, увага, мислення, пам'ять, саморозвиток особистості.

\section{Cite this article as:}

Mykytiuk, S. O., \& Mykytiuk, S. S. (2019). The Psychological Component of the Resource-Based Approach in Higher Pedagogical Education. International Journal of Education and Science, 2(3), 8-16. doi:10.26697/ijes.2019.3.1

The electronic version of this article is the complete one and can be found online at: http://ijes.culturehealth.org/index.php/en/archive

This is an Open Access article distributed under the terms of the Creative Commons Attribution License, which permits unrestricted use, distribution, and reproduction in any medium, provided the original work is properly cited (http://creativecommons.org/licenses/by/4.0/deed.en). 